Article

\title{
Applying Hierarchical Task Analysis to Depict Human Safety Errors during Pesticide Use in Vineyard Cultivation
}

\author{
Mario Fargnoli ${ }^{1,2, *(\mathbb{D})}$, Mara Lombardi ${ }^{1} \mathbb{D}$ and Daniele Puri ${ }^{3}$ \\ 1 Department of Chemical Engineering Materials Environment (DICMA), Sapienza-University of Rome, \\ via Eudossiana 18, 00184 Rome, Italy \\ 2 Ministry of Agriculture, Food and Fishery, DISR I, via XX Settembre 20, 00187 Rome, Italy \\ 3 National Institute for Insurance against Accidents at Work (INAIL), Via Fontana Candida, \\ 1-00078 Monte Porzio Catone (RM), Italy \\ * Correspondence: mario.fargnoli@uniroma1.it
}

Received: 28 June 2019; Accepted: 17 July 2019; Published: 19 July 2019

\begin{abstract}
The use of pesticides in agriculture is a significant problem at a global level, not only from an environmental perspective but also from the farmers' health and safety point of view. In the literature, several studies have discussed the safe behavior and risk perception of farmers. However, human errors when dealing with pesticides and the related work equipment are rarely considered. To reduce this research gap, a study of the human safety errors in pesticide use based on hierarchical task analysis is proposed. In particular, such a bottom-up approach was applied to vineyard cultivation and considered all the activities that operators carry out when using pesticides. The results of this study showed that most of the identified human errors were action errors, i.e., potential failures of the operator in completing the activity successfully. In addition, retrieval and checking errors resulted in being rather common. These outputs shed light on the gap between the information received and the practical need for operators to reduce their failure to perform specific activities. Therefore, while the present study augments current knowledge on the safe use of pesticides, further research is needed to address human errors in agricultural activities, thus extending these results to a larger sample size as well as to other cultivation types.
\end{abstract}

Keywords: human safety; human error; occupational health and safety (OHS); hierarchical task analysis (HTA); systematic human error reduction and prediction approach (SHERPA); farmers' behavior; pesticide application; vineyard cultivation

\section{Introduction}

In recent years, the proper use of pesticides in the agricultural field has been given more attention and importance thanks to increasing awareness of the impact of these substances on the health and safety of humans, as well as on the eco-system [1-4]. This has led to the issue of stricter standards and regulations with respect to the introduction of new products into the market and their labelling criteria [5-7]. Accordingly, a more sustainable use of pesticides has been promoted, for instance, in European Union (EU) countries, the issuance of Directive 2009/128/EC [8] has led to significant changes at a practical level by introducing specific measures for the training of users and the inspection of the equipment used for pesticide application $[9,10]$. The users of pesticides need specific training in order to mitigate occupational health and safety (OHS) issues and to acquire sufficient knowledge regarding the hazards and risks associated with pesticides. These include: 
1. The safe use of pesticide application equipment and its maintenance.

2. Specific risks linked to the use of pesticide application equipment and the relevant risk management measures.

3. Safe working practices for storing, handling and mixing pesticides, and disposing of empty packaging, other contaminated materials and surplus pesticides.

4. The proper selection and use of personal protection equipment (PPE) to reduce the exposure of users.

Additionally, inspection of the pesticide application equipment needs to be carried out at regular intervals in order to guarantee the proper health and safety requirements. Therefore, the training of operators must include proper procedures for preparing the equipment for pesticide application, including its calibration, and for its operation with minimum risks to the user. This stringent framework of requirements is aimed at reducing the quantity of pesticides used in agriculture, as well as avoiding their improper use, which can have negative effects on the health and safety of farmers, on the quality of soil and water [11-13], and at a more general level on the whole society [14,15]. As noted by Damalas and Koutroubas [16], despite the fundamental role of pesticides in augmenting food security and economic growth, especially in developing countries, they can have dire consequences on both human health and the environment if used in an improper manner. Accordingly, the evaluation of the use of pesticides and the related risk perception of farmers is considered an urgent matter [17]. As observed by Palis et al. [18], there is a lack of knowledge about farmers' perceptions regarding risks related to the use of pesticides, and consequently, with respect to farmers' attitudes about safe behaviors aimed at reducing their exposure. It should be noted that while the misuse of pesticides can be related to a lower level of education and the means of farmers, especially in developing countries [19], economic reasons associated with a low risk perception can lead farmers to disregard regulations and provisions for safe pesticide management [20]. The different and interwoven factors that determine the safety behavior of farmers in pesticide use were investigated by Sharifzadeh et al. [21], who argued that even though farmers have a good understanding of the importance of safety behaviors, they still tend to behave improperly. In other words, as noted by Caffaro et al. [22], a good level of available information on safety issues does not always guarantee subsequent safe behavior by the farmer. The behavior of farmers only improves when they comprehend the effectiveness of the recommended actions on their protection and safety [23]. This is in line with the findings of Fan et al. [24], who highlighted that farmers get confused by the complexity of guidelines related to the proper use of pesticides; hence, they tend to misuse pesticides, reducing their protective behavior. Accordingly, the research related to the knowledge and attitudes on the use of pesticides needs to be further developed, focusing on farmers' practices [25]. In the agricultural field, several studies have investigated the safe behavior and risk perception of farmers. The human factors leading to accidents while using tractors were investigated by means of a task analysis approach, providing information of the farmers' safety attitude and behavior when dealing with this type of machinery [26]. Other studies have focused on the farmers' risk perception by means of scenarios related to the use of machinery and describing a real-life working situation [27]; the results showed that the farmers were aware of certain types of risks, particularly when these were associated to economic losses. Other studies have focused on the tendency of farmers to behave according to their past experiences rather than new working procedures [28], especially when no negative events have occurred [29]. In addition, the cognitive aspects of situation awareness, which play an important role in safe and efficient work practices, have been addressed and research has highlighted the impact of situation awareness lapses and other causal factors among tractor drivers [30]. However, farmers' attitudes towards proper pesticide handling is not well known yet [31]. In fact, further studies on behavioral factors in pesticide use, including risk perception, are of major importance for effective risk management [32]. To address these issues, a human-centered approach is needed with the aim of investigating the different phases that characterize the work activities [33,34]. As argued by several authors in different fields, human error analysis can allow a better understanding of how human interaction with work tasks might lead to accidents and 
incidents [35-37], since normative approaches do not properly consider the characteristics of the work processes [38].

Based on the above considerations, the present study aims to reduce this research gap through an investigation of farmers' behavioral reliability in pesticide use. The analysis concerns the activities related to pesticide use in vineyard cultivation, by means of interviews of a group of Italian farmers. For this purpose, the hierarchical task analysis (HTA) method [39] was applied for the definition of the goals of the work activities and their mutual interactions, as a supporting tool for the identification of context specific human errors while performing these activities [40]. Furthermore, the systematic human error reduction and prediction approach (SHERPA) method [41] was used to investigate farmers' behavior and error types that might occur when performing the identified working activities. The remainder of the paper is structured as follows: in Section 2, the materials and methods of the study are described, and in particular, we introduce both the context of the study and the proposed research methodology. Section 3 describes the case study, while the results achieved are discussed in Section 4. Section 5 concludes the paper.

\section{Materials and Methods}

\subsection{Context of the Study}

Vineyard cultivation in one of the most widespread agricultural activities in Italy $[42,43]$ as vinification has been practiced for thousands of years in all parts of the country $[44,45]$. The number of vineyard holdings in European Union (EU) countries compared to the total surface area used for these activities is shown in Figure 1 [46] (note that all the values are expressed in thousands).

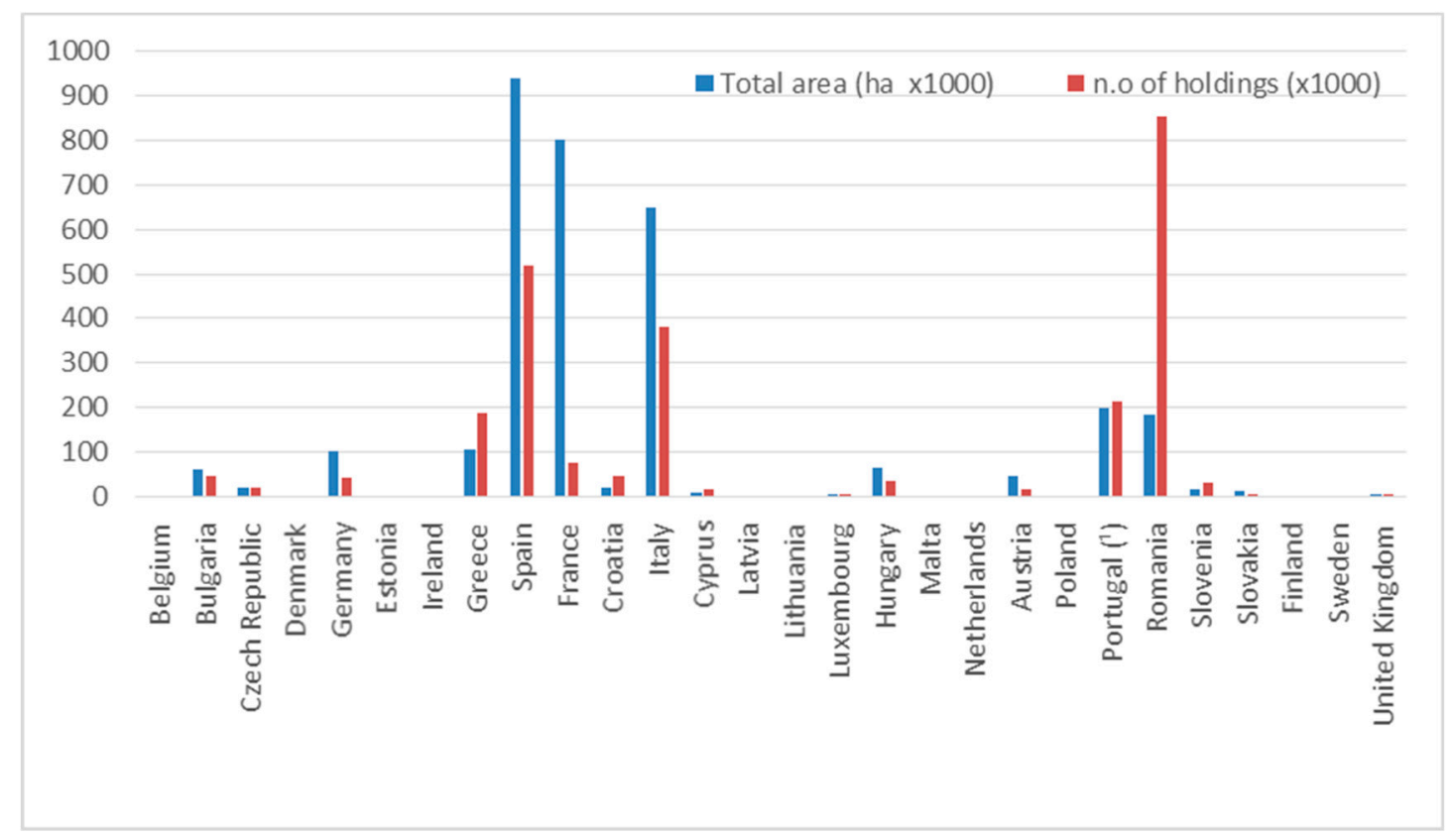

Figure 1. Vineyard holdings in the EU (all values are expressed in thousands), source [46].

The data shows that the average surface area used for vineyard cultivation in Italy is about 1.7 hectares per company; so, while there are many large companies operating in this sector, the majority of producers are small-sized and family run companies. These small companies are also regarded as critical with respect to health and safety issues [47,48], because they find it difficult to comply with safety requirements due to their lack of resources [49,50]. In addition, we have to consider that the average age of Italian farmers is rather high compared to the other EU countries; in fact, 
according to official statistics the majority of agricultural holders (i.e., more than $50 \%$ ) are more than 60 years old [46].

As far as the use of pesticides is concerned, data provided by the Ministry of Agriculture, Food, Fishery and Tourism show that in the period since the introduction of Directive 2009/128/EC on 26 November, 2015 up until the end of 2017, about 450,000 training courses for pesticide users were carried out in Italy. Hence, despite the great effort made by national and regional authorities, it can be assumed that a large number of pesticide users still need to be trained in order to fulfil the legislative requirements.

\subsection{Methods}

In order to achieve the above-mentioned goal, a procedure based on the HTA and SHERPA tools was applied, in combination with interviews with operators. In particular, the application of HTA allows a detailed decomposition of the working tasks, facilitating the analysis of behavioral aspects by means of SHERPA. In fact, the interviewed operators can easily provide specific information on possible deviations from the correct way of performing each specific activity. Following such a systematic approach, the potential bias of the analysts is reduced and also unexperienced analysts can obtain consistent results [51]. Actually, several studies in the field of human reliability analysis (HRA) have demonstrated that the systematic procedure required by the synergic use of HTA and SHERPA allows analysts to reduce the subjectivity of the assessment and provide reliable outputs [52-54].

\subsubsection{Hierarchical Task Analysis (HTA)}

Numerous examples of HTA studies can be found in the literature [55-57]. In this context, HTA was used to divide the overall working task into sub-tasks; elementary tasks; and specific activities in a hierarchical manner by means of a tree diagram [36], as shown in Figure 2.

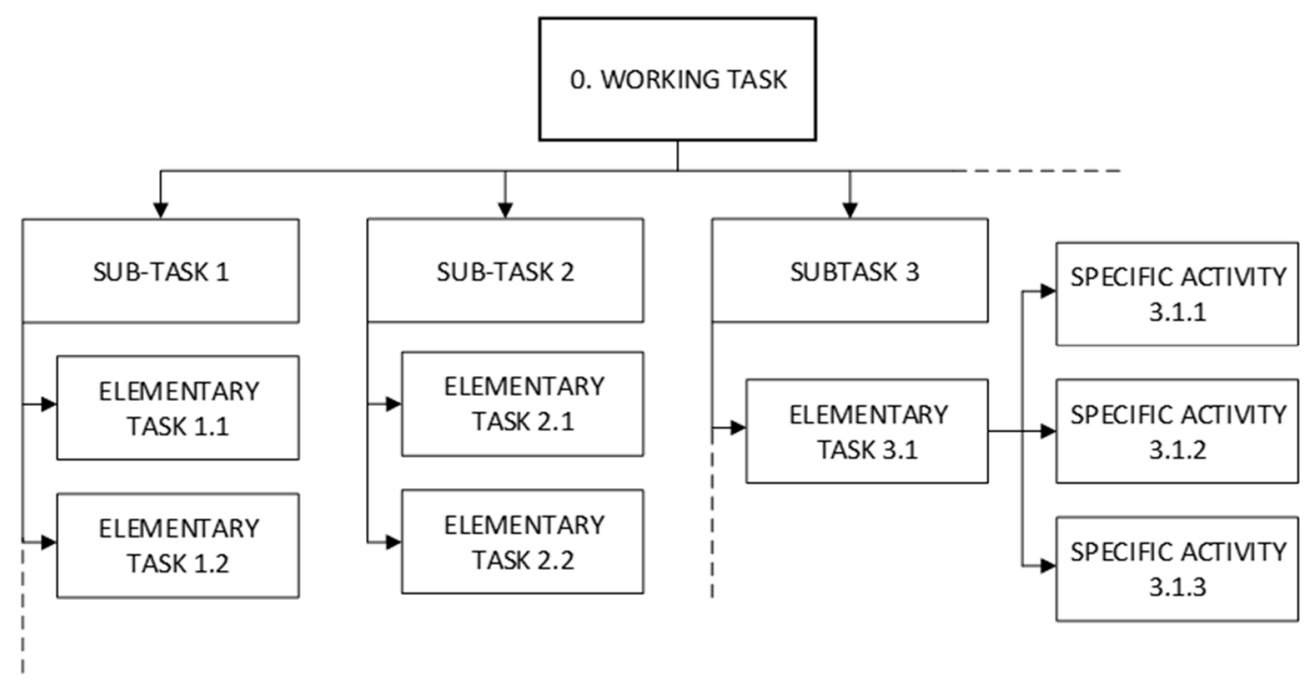

Figure 2. Scheme of the hierarchical task analysis (HTA) method used in the analysis (adapted from [26]).

\subsubsection{Systematic Human Error Reduction and Prediction Approach (SHERPA)}

The SHERPA method developed by Embrey [41] (who further expanded it into the predictive human error analysis (PHEA) technique [58]) is considered one of the most effective tools for investigating human reliability in performing a certain task, taking into account the cognitive aspects of human error. Several studies describing the use of this tool can be found in the literature, mainly addressing the reliability of operators in safety critical industries [40]. For example, Ghasemi et al. [59] used SHERPA to identify human error types in control units of the petrochemical industry, while 
Harris et al. [51] used this tool to analyze aircraft pilots, and suggested that that error types such as "actions" and "checks" are particularly suited to the analysis of these work tasks. Other examples of the SHERPA application can be found in the analysis of heavy machinery operators in the construction sector [34], as well as in the analysis of the task of administering drugs to hospital patients [35]. Other studies have focused on extensions of the SHERPA method [53].

The core of the method is the classification of human error types into five main categories (error types): Action (A); Checking (C); Retrieval (R); Communication (C); and Selection (S). For each category, a set of "error modes" is provided in order to classify the human behavior. Lane et al. [35] reported 24 sub-categories (error modes), as synthetized in Table 1.

Table 1. Systematic human error reduction and prediction approach (SHERPA) error types and modes (adapted from [35]).

\begin{tabular}{|c|c|}
\hline Error Type & Error Mode \\
\hline $\begin{array}{c}\text { Action errors (A), when the human action changes } \\
\text { the status of the system }\end{array}$ & $\begin{array}{c}\text { A1 Operation too long/short } \\
\text { A2 Operation mistimed } \\
\text { A3 Operation in wrong direction } \\
\text { A4 Operation too little/much } \\
\text { A5 Misalign } \\
\text { A6 Right operation on wrong object } \\
\text { A7 Wrong operation on right object } \\
\text { A8 Operation omitted } \\
\text { A9 Operation incomplete } \\
\text { A10 Wrong operation on wrong object }\end{array}$ \\
\hline $\begin{array}{l}\text { Checking errors }(C) \text {, when the operator fails to verify, } \\
\text { check the status of the system }\end{array}$ & $\begin{array}{cl} & \text { C1 Check omitted } \\
\text { C2 Check incomplete } \\
\text { C3 Right check on wrong object } \\
\text { C4 Wrong check on right object } \\
\text { C5 Check mistimed } \\
\text { C6 Wrong check on wrong object }\end{array}$ \\
\hline $\begin{array}{l}\text { Retrieval errors }(\mathrm{R}) \text {, if the operator fails to retrieve } \\
\text { information, e.g., from a work procedure }\end{array}$ & $\begin{array}{c}\text { R1 Information not obtained } \\
\text { R2 Wrong information obtained } \\
\text { R3 Information retrieval incomplete }\end{array}$ \\
\hline $\begin{array}{l}\text { Communication errors }(\mathrm{I}) \text {, when the operator fails to } \\
\text { transfer information to another person }\end{array}$ & $\begin{array}{l}\text { I1 Information not communicated } \\
\text { I2 Wrong information communicated } \\
\text { I3 Information communication incomplete }\end{array}$ \\
\hline $\begin{array}{l}\text { Selection errors }(S), \text { when the operator makes the } \\
\text { wrong choice among different alternatives }\end{array}$ & $\begin{array}{c}\text { S1 Selection omitted } \\
\text { S2 Wrong selection made }\end{array}$ \\
\hline
\end{tabular}

\subsubsection{Research Methodology}

More specifically, the application process of the above mentioned HRA tools can be synthesized in the following procedure:

1. Analysis of the working activities: for this purpose, the HTA method can be used in order to break the working task down into its components [35]. The definition of the hierarchical framework of the working activities can be carried out considering references including technical standards, safety manuals and the experts' opinions [53].

2. Classification of the working task components: for each task step (considering the lowest level of each tree branch), the possible error modes are defined and classified in accordance with the criteria illustrated in Table 1. For this purpose, interviews with operators are a key factor for depicting how accidents, incidents and near-misses might occur when performing each specific activity.

3. Consequences definition: the potential consequences of each error mode are defined. 
4. Errors assessment: each error is evaluated in a qualitative manner considering its probability of occurrence $(\mathrm{P})$ and its criticality (C). For this purpose, the risk matrix [60] criteria can be used, where the probability of occurrence can be estimated on a 1-5 scale (from $1=$ very unlikely to $5=$ very likely); and the criticality of consequences can be estimated by means of a 1-5 scale (from $1=$ minor effects to $5=$ catastrophic effects). It should be noted that in this context, we considered that the latter factor mainly referred to occupational health and safety consequences.

5. Risk level definition: the estimation of the risk level (R) related to each error type is performed by combining the probability of occurrence $(\mathrm{P})$ and its criticality $(\mathrm{C})$ by means of the following equation:

$$
\mathrm{R}=\mathrm{P} \times \mathrm{C},
$$

The output consists of the classification of the human error risk level based on the criteria shown in Table 2.

6. Implementation of the SHERPA tables: the results of the previous steps are used to fill in the SHERPA table [35,59], where remedial measures are indicated for each error mode.

Table 2. Levels of the human error risk (R).

\begin{tabular}{ccc}
\hline $\mathbf{R}$ & Level & Meaning \\
\hline$\leq 5$ & I & Acceptable level risk \\
\hline $6-9$ & II & Medium level of risk \\
\hline $10-15$ & III & High level of risk \\
\hline $16-25$ & IV & Unacceptable level of risk \\
\hline
\end{tabular}

\section{Case Study}

As mentioned above, the current study consists of the analysis of the human errors that might occur when using pesticides in vineyard cultivation. With this goal in mind, we interviewed 11 operators belonging to 7 different companies. The selected operators use 2 different types of atomizers: mounted sprayers, whose capacity ranges from 400 to $500 \mathrm{~L}$; and trailed sprayers, whose capacity ranges from 600 to $1000 \mathrm{~L}$. This choice was made in order to make the analysis as homogenous as possible with regard to the work activities: in fact, the above-mentioned equipment has similar characteristics for the application of pesticides (double nozzles with return suction, a propeller with changing pitch blades, and a remote pressure regulation distributor on the tractor). It should be noted that all the operators interviewed had received the specific training course for pesticide users in accordance with the requirements of Directive 2009/128/EC. Their experience in vineyard cultivation ranged from 5 to 35 years while their ages ranged from 23 to 64 years old. As far as the cultivated area is concerned, the average size of each cultivated area is about 2.07 hectares (ranging from 0.5 to 4 hectares) located in the Lazio and Campania regions (Italy).

Following the procedure described in the previous section, the first step of the analysis consisted of the definition of the work activities; a scheme representing sub-tasks and elementary tasks is shown in Figure 3.

In doing so, legislative requirements, technical reports and standards were considered in order to depict the proper procedure for performing each subtask/elementary task/specific activity. In addition, the National Action Plan (NAP) concerning the sustainable use of pesticides was taken into account [61] as it establishes the mandatory requirements that must be satisfied for the correct use of pesticides in order to reduce their negative impacts. Table 3 shows an excerpt of the hierarchical decomposition of work activities, while the complete list of activities is reported in Appendix A. 


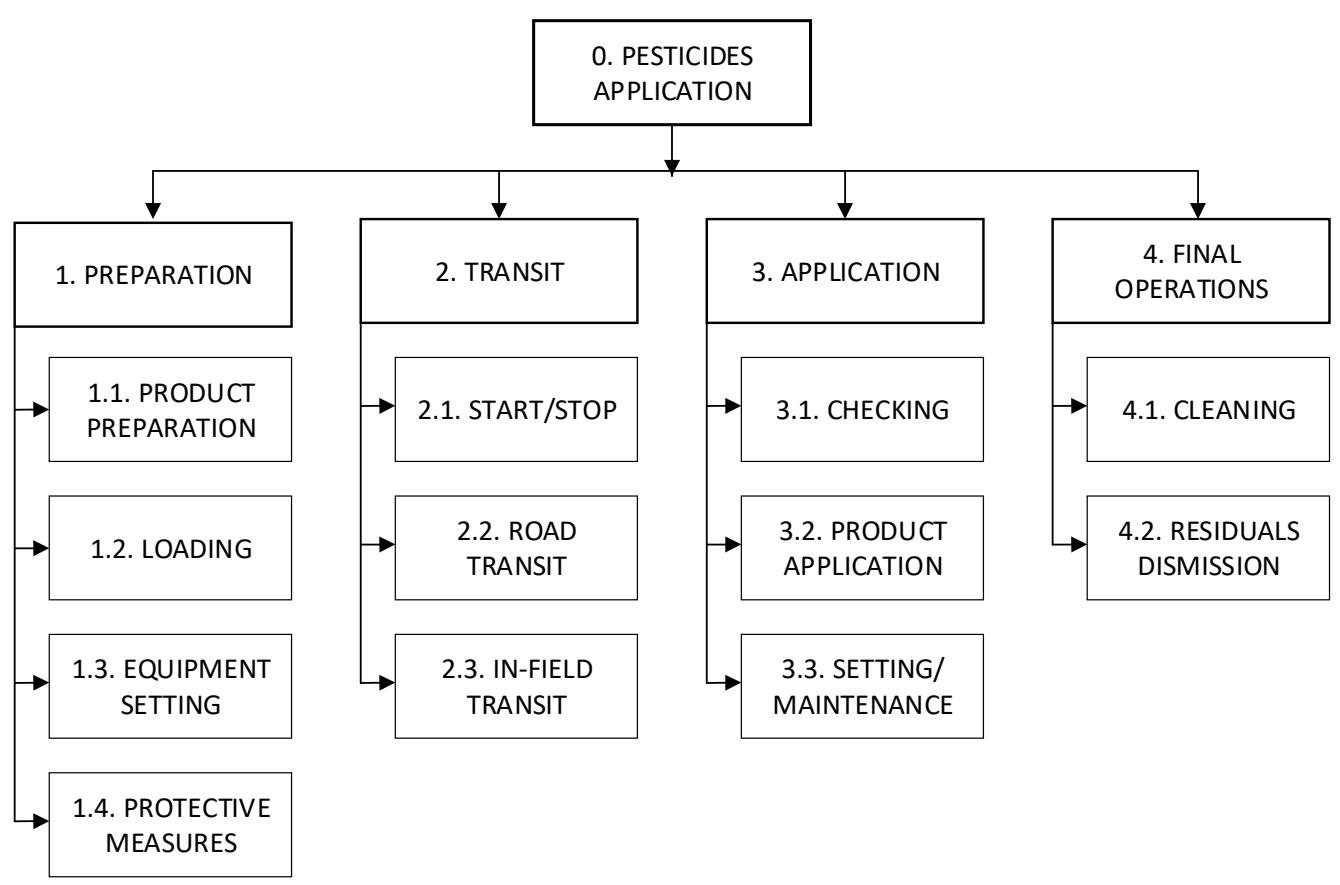

Figure 3. Scheme of the HTA application.

Table 3. Excerpt of the hierarchical decomposition in the list of sub-tasks, elementary tasks and specific activities.

\begin{tabular}{|c|c|c|}
\hline Subtask & Elementary Task & Specific Activity \\
\hline \multirow{15}{*}{$\begin{array}{c}\text { 1. Preparation } \\
\text { Plan 1: do } 1.4 \text { or } 1.3 \text { then } \\
1.1,1.2\end{array}$} & \multirow{9}{*}{$\begin{array}{c}\text { 1.1. Product preparation } \\
\text { Plan 1.1: do 1.1.1, 1.1.2, 1.1.3, } \\
\text { 1.1.4, 1.1.5, 1.1.6, 1.1.7, 1.1.8, } \\
\text { 1.1.9 in order }\end{array}$} & 1.1.1. Check the treatment register \\
\hline & & 1.1.2. Check the weather conditions \\
\hline & & 1.1.3. Take the product out of store \\
\hline & & 1.1.4. Read the product label \\
\hline & & 1.1.5. Check the expiry date \\
\hline & & 1.1.6. Check safety instructions \\
\hline & & 1.1.7. Dose the product \\
\hline & & 1.1.8. Store the product not used \\
\hline & & 1.1.9. Update the treatment register \\
\hline & \multirow{6}{*}{$\begin{array}{l}\text { 1.2. Loading } \\
\text { Plan 1.2: do } 1.2 .1,1.2 .2,1.2 .3 \\
\text { or } 1.2 .4 \text {, then } 1.2 .5,1.2 .6\end{array}$} & 1.2.1. Fill the tank with the water \\
\hline & & 1.2.2. Fill the tank with the product \\
\hline & & 1.2.3. Mix the components (if present) \\
\hline & & 1.2.4. Fill the supplementary water tank \\
\hline & & 1.2.5. Check the tank tap \\
\hline & & 1.2.6. Update the tank label \\
\hline
\end{tabular}

It should be noted that different procedures can be used for the internal cleaning of the tank depending on the specific situation and equipment $[62,63]$. Therefore, these operations were not considered in the current study. Then, based on the results of the interviews concerning the description of the activities carried out for each elementary task/specific activity, behavioral errors were identified and classified following the criteria reported in Table 1. The final step involved the implementation of the SHERPA table, which depicts the analysis of human error related to the overall working task. 


\section{Discussion of Results}

\subsection{Case Study Results}

The results obtained showed that in 75 different specific activities, 171 human error modes emerged. As shown in Figure 4, action errors are the most common error (50.88\%) while checking errors represent $25.73 \%$ of the total.

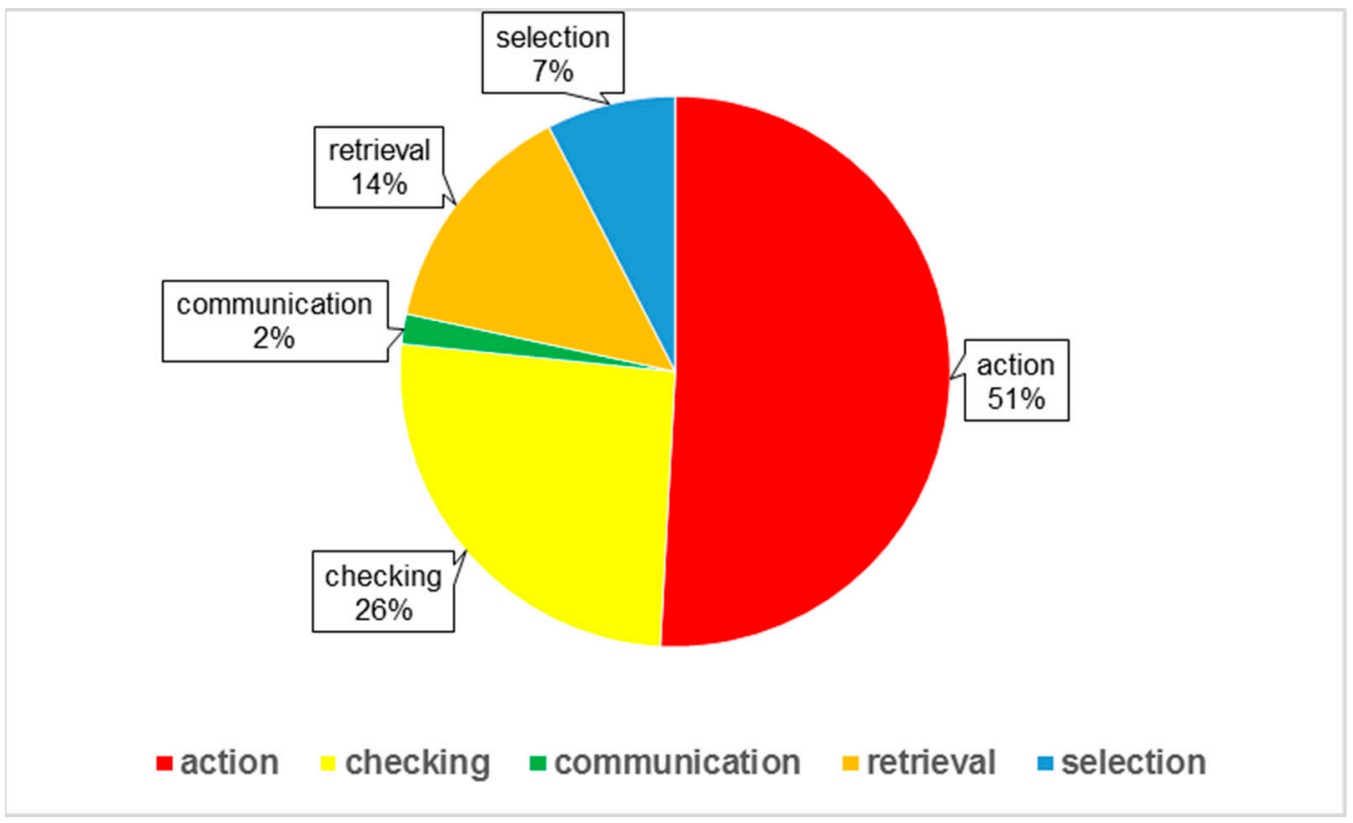

Figure 4. Percentage of the error types that emerged from the analysis.

More specifically, as shown in Figure 5, the most important human errors found in the analysis are the following (in alphabetical order):

- A2. The operator mistimes the activity, especially when dealing with the equipment, for instance, when getting in/out of the tractor, driving and maneuvering it.

- A3. The operator performs the activity incorrectly, as when an operation is carried out without following the instructions, e.g., when performing maintenance activities on the atomizer without switching off the tractor.

- A7. The operator performs the wrong operation on the right object, as for example, when they activate the tractor or the equipment, mix the product's components incorrectly, miscounts the dose of components, puts the product in the wrong place, parks the tractor in a wrong manner, or uses PPE incorrectly.

- A8. The operator does not perform a requested activity, as for example, they omit to update the treatments' register, to label the equipment with the information of the pesticide used, fill the tank with supplementary water for hand-washing, etc.

- $\quad$ C1. The operator omits checking important elements that characterize the activity, for example, checking the weather conditions (e.g., the wind speed), checking the information reported on the products' label (e.g., safety information, expiry date), as well as checking the "three points" attachment between the tractor and the atomizer, or the PTO (power take off) protection.

- C5. The information acquired during checking operations is mistimed, as for example, when the operator fails to pay attention to the equipment parameters, e.g., the tractor speed when driving or the atomizer pressure when applying the product. 
- R1. Important information on the specific activity is not obtained, as when the operator fails to read the pesticide labels or the PPE instructions check the correct PPE; check the atomizer pressure, etc.

- R2. Wrong information is obtained, for example, when the operator reads the pesticide labels and the safety instructions incorrectly.

- S2. The operator makes a wrong selection, for example, when the wrong pesticide is selected to prepare the product, the wrong PPE is used, or an unsafe area to park the tractor for loading or maintenance operations is selected.

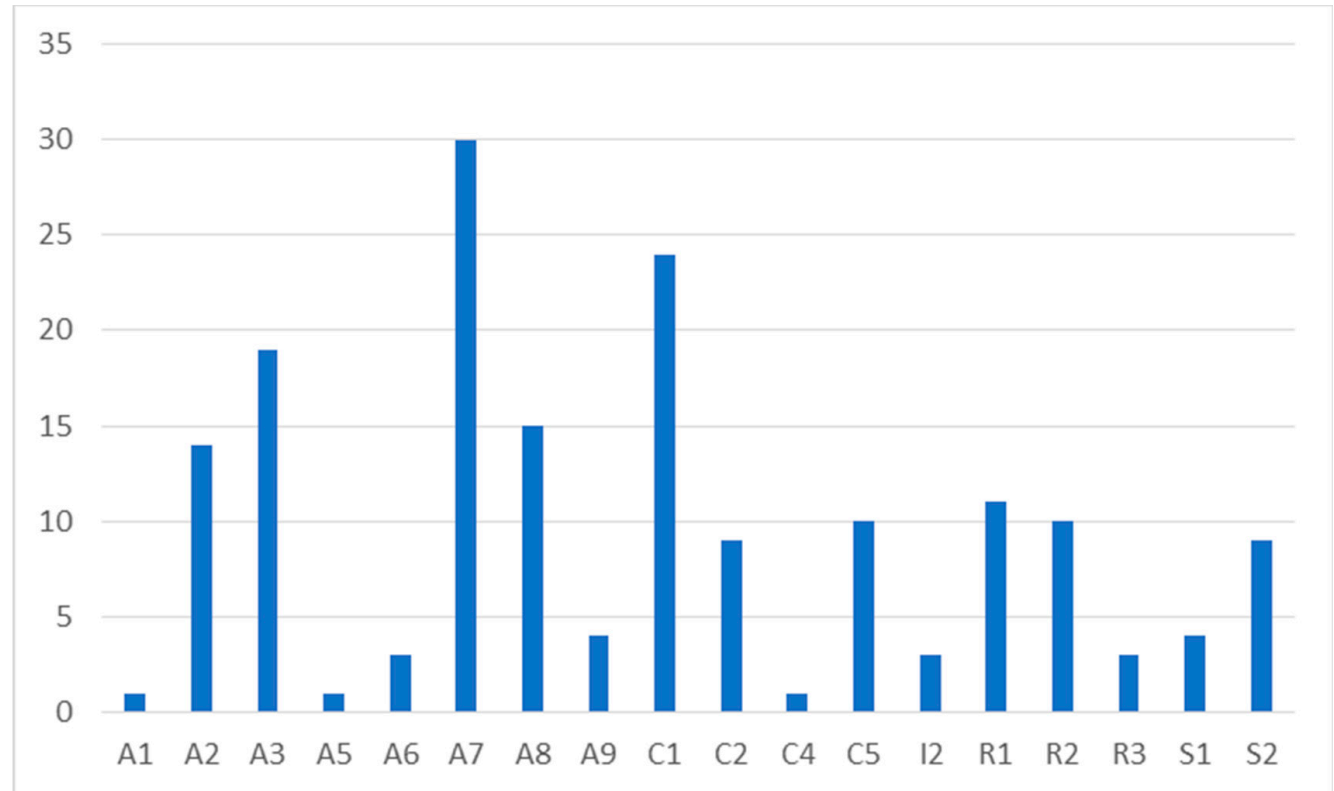

Figure 5. The number of different error modes that emerged from the analysis.

The SHERPA method also allowed us to analyze the level of risk associated with the identified human errors. In fact, as shown in Table 4, the SHERPA table provides information concerning the possible consequences of the error mode, its probability of occurrence $(\mathrm{P})$ and criticality $(\mathrm{C})$, as well as its remedial measures. While the occurrence of errors was computed considering the results of the interviews, their criticality was evaluated based on the consequences on the health and safety of the operators.

Table 4. Excerpt of the SHERPA table.

\begin{tabular}{|c|c|c|c|c|c|c|}
\hline Specific Activity & Error Mode & Description & Consequences & $\mathbf{P}$ & C & Remedial Measures \\
\hline \multirow[t]{2}{*}{$\begin{array}{l}\text { 1.1.3. Take the } \\
\text { product out of } \\
\text { store }\end{array}$} & A6 & $\begin{array}{c}\text { The operator takes } \\
\text { the wrong product } \\
\text { from the storage } \\
\text { closet }\end{array}$ & $\begin{array}{l}\text { A wrong product is used } \\
\text { for the treatment }\end{array}$ & 2 & 4 & $\begin{array}{l}\text { Preserve the package } \\
\text { integrity of the } \\
\text { products }\end{array}$ \\
\hline & S1 & $\begin{array}{l}\text { Select the wrong } \\
\text { product }\end{array}$ & $\begin{array}{l}\text { A wrong product is used } \\
\text { for the treatment }\end{array}$ & 2 & 4 & $\begin{array}{l}\text { Specific operator } \\
\text { training }\end{array}$ \\
\hline \multirow{2}{*}{$\begin{array}{l}\text { 1.1.4. Read the } \\
\text { product label }\end{array}$} & R1 & $\begin{array}{c}\text { The operator fails } \\
\text { in reading the } \\
\text { label }\end{array}$ & $\begin{array}{l}\text { A wrong product/dose is } \\
\text { used for the treatment } \\
\text { Inappropriate safety } \\
\text { measures are implemented }\end{array}$ & 3 & 4 & $\begin{array}{l}\text { Preserve the package } \\
\text { integrity of the } \\
\text { products } \\
\text { Specific operator } \\
\text { training }\end{array}$ \\
\hline & $\mathrm{R} 2$ & $\begin{array}{l}\text { The operator } \\
\text { reads the label } \\
\text { incorrectly }\end{array}$ & $\begin{array}{l}\text { A wrong product/dose is } \\
\text { used for the treatment } \\
\text { Inappropriate safety } \\
\text { measures are implemented }\end{array}$ & 3 & 4 & $\begin{array}{l}\text { Preserve the package } \\
\text { integrity of the } \\
\text { products } \\
\text { Specific operator } \\
\text { training }\end{array}$ \\
\hline
\end{tabular}


The output of this analysis is summarized in Figure 6, where the majority of human error risks are classified as medium-level risks (51.46\%) while unacceptable risks represent $3.51 \%$ of the total.

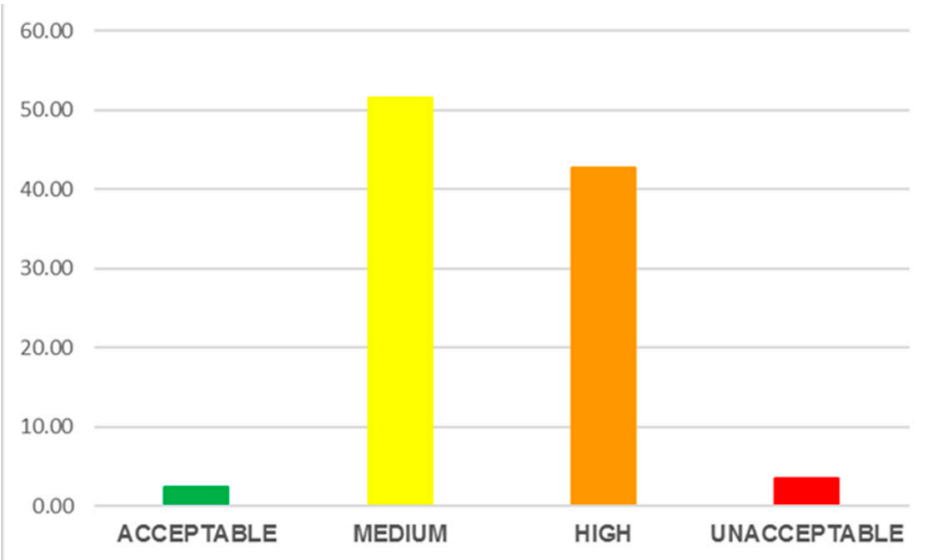

Figure 6. Level of risk (expressed as percentages) associated with the error modes identified in the analysis (i.e., the misbehaving risk level).

It has to be pointed out that the proposed approach is aimed at identifying and classifying human error types when farmers deal with pesticide application and the related equipment. Therefore, unlike traditional risk assessment tools [64], the proposed HRA methodology is focused on understanding how and when (i.e., on which occasion) the operator might fail. In fact, rather than estimating the probability of occurrence and severity of accidents, HRA tools investigate human performance or human actions as the root or triggering cause of undesired events [65]. Hence, the level of risk estimated in Figure 6 has to be considered in this context, i.e., the criticality of certain specific activities from a human behavior point of view. For these reasons, comparing the results obtained with accident statistics only provides a partial validation of them, as demonstrated for example, by Elkind [66] and Caffaro et al. [67].

Further detailed analysis of the risk of misbehavior revealed that a few error modes can lead to acceptable risks $(2.34 \%)$. This is due to the fact that in our study, we only took OHS criticalities into account, while other types of effects (e.g., the impact on the environment, the reduced production, etc.) were not considered. Accordingly, this also implies a low rate of unacceptable risks, since the number of errors that can cause catastrophic effects for the operator (i.e., the tractor roll-over caused by incorrect maneuvering while changing the vineyard line, operations carried out to regulate the atomizer without switching off the tractor, etc.) is limited. However, the large number of high-level risks $(42.69 \%)$ due to human errors highlights the critical nature of these activities, and how health and safety issues can be ignored by operators. This finding is in line with the study of Allahyari et al. [68], who noted the need to increase farmers' awareness of the adverse effects of pesticides on human health in order to enhance the proper use and management of these products. In addition, this result also supports the findings of other studies that have focused on the unsafe behavior of farmers because of a lack of risk awareness and risk perception among farmers [27,67,69,70].

\subsection{Research Insights}

The hierarchical decomposition of work activities allowed us to better characterize the activities usually performed when using pesticides in vineyard cultivation. This systematic outline can effectively illuminate the nature of the actions that the operator performs, e.g., decision making, diagnosis, monitoring, etc. [39], and it provides a cognitive perspective to the analysis of work activities. Such a perspective is consistent with the research issues suggested by Irwin et al. [30], who stressed the need to consider the cognitive aspects of work activities to augment safe and efficient work practices in farming. 
Furthermore, the outputs of HTA represent a framework based on which human errors can be effectively elucidated [35], which facilitated the definition of their nature in order to better address remedial measures. The study showed that most of the identified human errors are action errors, i.e., potential failures of the operator to complete the activity successfully. On the one hand, such a finding indicates the lack of knowledge and awareness of risks related to improper use of pesticides at a practical level. In other words, while a general knowledge of health and safety concerns on the use of pesticides emerged, the risk of failing to apply such knowledge at the practical level is consistent. Merging this result with other outputs of the analysis, such as the rather random retrieval errors and the large number of checking errors, it can be assumed that there is a gap between the information received (i.e., the acquired knowledge) and the practical need to reduce errors in performing specific activities. This supports the points made by Yuantari et al. [25] and Reizei et al. [71], which highlight the importance of the quality of training courses that should be more tailored to the practical needs and working situations of farmers. On the other hand, the results achieved also highlight that the operators' perception of risk is often reduced because of their lack of comprehension of the information received (retrieval errors), as for example, the information on the product labels and instructions for the equipment regulation/calibration. This finding adds to the insights of previous studies (e.g., Caffaro et al. [72], Vigoroso et al. [73], Kapeleka and Mwaseba [74], and Rother [75]), by providing additional knowledge in the field of the safe use of pesticides and the related work equipment.

Moreover, the large number of possible omitted/incomplete operations and controls that are not perceived as significant can be ascribed to both fatigue and stress caused by working schedules that are strictly ruled by seasonality and weather conditions, which is in agreement with the results of Irwin and Poots [27].

Overall, the present study proposes a procedure for the analysis of human errors based on the coordinated use of the HTA and SHERPA methods. Such an approach aims to extend the benefits of hierarchical task analysis $[35,59]$ to the study of human safety and human reliability in the agricultural context. Following a bottom up approach for the investigation of possible accidents and incidents allows for a more effective and thorough analysis of health and safety issues $[37,76]$. Hence, unlike other studies that have dealt with human safety in agriculture (e.g., $[15,30,77,78])$, the present study proposes a systematic and inductive approach to depict human error types and modes, and provides timely information for the implementation of remedial measures. In fact, the use of HTA allows the breakdown of work phases into elementary tasks/specific activities, thus providing an easy-to-use framework for the application of SHERPA. Then, the information provided by interviewed operators can be used in an objective manner by means of the SHERPA taxonomy to define the error modes and types [51]. Accordingly, this procedure can be replicated easily, thus reducing the occurrence of mistakes by the analysts. Moreover, differently from other HRA tools, the results provided by the combined use of HTA and SHERPA can be considered reliable as they have been tested in numerous different contexts $[52,53,70,79]$.

In addition, such an approach fits well with the analysis of work activities related to the use of pesticides, where the combined use of toxic products and dangerous equipment exposes farmers to different and multifaceted types of errors and risks, while requiring compliance to an interwoven combination of mandatory requirements [80]. To the authors' knowledge, this study represents a novelty in the sector, and can be considered as a basic framework for further and more detailed analyses.

\subsection{Limitations}

Besides the beneficial implications, the limitations of the current study also need to be addressed. From a methodical point of view, difficulties might arise in the application of the SHERPA method as it can be a time-consuming process [56]. Hence, although numerous studies have proposed the use of these tools in different contexts and provide useful guidelines, caution is needed in selecting the goal of the analysis (i.e., the overall task and sub-tasks to be analyzed) in the specific context [81]. Moreover, the qualitative nature of the results requires a larger sample size for their validation. Therefore, the 
present study should be considered as a first attempt that aimed to further knowledge of human safety in pesticide use, since the focus of qualitative case study research is represented by the generation of propositions that are believed to be wider [82]. As far as the case study is concerned, we also have to underline the difficulty we had in finding a standardized procedure for the internal cleaning of the equipment, in order to determine deviations caused by human errors. In fact, most of the operators that were interviewed used aged atomizers, which do not require the technical features requested by Directive 2009/127/EC for new machinery. Also, different procedures to avoid point source contamination have been suggested depending on both the specific context, and the size and shape of the equipment used [62,83-88]. Moreover, to the authors' knowledge a few companies have at their disposal a specific area for the cleaning of the application equipment, while in the considered sample none of the interviewed companies has this type of facility. In fact, from the interviews it emerged that the most widespread practice, especially among small-sized companies, consists of diluting the residuals in the tank with additional water (usually the supplementary water for washing hands is used) and spraying the obtained mixture in the field (usually on the same vineyard just treated). However, such a practical procedure is followed without paying attention to the quantity of residuals and added water, thus generating a new mixture whose toxicity is unknown and always different. For these reasons, we decided to exclude the "internal cleaning of the equipment" from the current study, as it deserves a more detailed and specific investigation.

\section{Conclusions}

The present work investigates human errors in the activities related to the use of pesticides in vineyard farming. The proposed approach relies on well-known tools for the analysis of human behavior, and uses a bottom-up perspective based on the hierarchical task analysis. Numerous studies in different contexts and sectors have proved that the synergic use of HTA and SHERPA methods constitutes a reliable means for the analysis of human errors, thus confirming the validity of the proposed approach.

Moreover, the application of these traditional HRA tools to the analysis of agricultural activities represents a novelty in the literature. Thus, we believe that the present study increases the body of knowledge in this research context. The application of the proposed approach to a concrete case study provided useful information for a better understanding of farmers' behavior in the use of pesticide, as well as practical clues to improve safety measures to reduce health and safety risks for farmers. In addition, such an approach to analyzing human errors when dealing with pesticides and the related application equipment provides a frame of reference that can be easily replicated and extended to other case studies.

The proposed procedure, like any other novel approach, needs to be further tested considering larger sized case studies and different contexts in order to refine it, and augment its validity and applicability. Hence, practitioners and researchers are invited to contribute to its further development.

Author Contributions: Conceptualization, M.F., M.L., D.P.; methodology, M.F., M.L., D.P.; validation, M.F., M.L., D.P.; writing-Review and Editing, M.F., M.L., D.P.

Acknowledgments: The authors wish to thank Pasquale Falzarano for his support in the case study context definition.

Conflicts of Interest: The authors declare no conflict of interest. 


\section{Appendix A}

Table A1. List of sub-tasks, elementary tasks and specific activities.

\begin{tabular}{|c|c|c|}
\hline Subtask & Elementary Task & Specific Activity \\
\hline \multirow{27}{*}{$\begin{array}{c}\text { 1. Preparation } \\
\text { Plan 1: do } 1.4 \text { or } 1.3 \text { then } 1.1 \text {, } \\
1.2\end{array}$} & \multirow{9}{*}{$\begin{array}{c}\text { 1.1. Product preparation } \\
\text { Plan 1.1: do 1.1.1, 1.1.2, 1.1.3, } \\
\text { 1.1.4, 1.1.5, 1.1.6, 1.1.7, 1.1.8, } \\
\text { 1.1.9 in order }\end{array}$} & 1.1.1. Check the treatment register \\
\hline & & 1.1.2. Check the weather conditions \\
\hline & & 1.1.3. Take the product out of store \\
\hline & & 1.1.4. Read the product label \\
\hline & & 1.1.5. Check the expiry date \\
\hline & & 1.1.6. Check safety instructions \\
\hline & & 1.1.7. Dose the product \\
\hline & & 1.1.8. Store the product not used \\
\hline & & 1.1.9. Update the treatment register \\
\hline & \multirow{6}{*}{$\begin{array}{c}\text { 1.2. Loading } \\
\text { Plan 1.2: do } 1.2 .1,1.2 .2,1.2 .3 \text { or } \\
\text { 1.2.4, then } 1.2 .5,1.2 .6\end{array}$} & 1.2.1. Fill the tank with the water \\
\hline & & 1.2.2. Fill the tank with the product \\
\hline & & 1.2.3. Mix the components (if present) \\
\hline & & 1.2.4. Fill the supplementary water tank \\
\hline & & 1.2.5. Check the tank tap \\
\hline & & 1.2.6. Update the tank label \\
\hline & \multirow{8}{*}{$\begin{array}{l}\text { 1.3. Equipment preparation: } \\
\text { Plan 1.3: do 1.3.1, } 1.3 .2 \text {, then } \\
\text { 1.3.3, 1.3.4, 1.3.5, 1.3.6, 1.3.7, } \\
\text { 1.3.8 }\end{array}$} & 1.3.1. Verify the parking in the loading area \\
\hline & & $\begin{array}{l}\text { 1.3.2. Check the connection between tractor } \\
\text { and equipment }\end{array}$ \\
\hline & & 1.3.3. Check the PTO (if used) \\
\hline & & 1.3.4. Check the pump \\
\hline & & 1.3.5. Check the sprayer \\
\hline & & 1.3.6. Regulate the sprayer \\
\hline & & 1.3.7. Check the product tank \\
\hline & & 1.3.8. Check the supplementary water tank \\
\hline & \multirow{4}{*}{$\begin{array}{c}\text { 1.4. Protective measures } \\
\text { Plan 1.4: do 1.4.1, then 1.4.2, } \\
\text { 1.4.3, 1.4.4 }\end{array}$} & 1.4.1. Read safety instructions \\
\hline & & 1.4.2. Check the PPE \\
\hline & & 1.4.3. Wear the PPE \\
\hline & & 1.4.4. Check the cabin filters (if present) \\
\hline \multirow{15}{*}{$\begin{array}{c}\text { 2. Transit } \\
\text { Plan 2: do } 2.1,2.2 \text { and/or } 2.3 \\
\text { then } 2.4\end{array}$} & \multirow{4}{*}{$\begin{array}{l}\text { 2.1. Start } \\
\text { Plan 2.1: do 2.1.1, 2.1.2, 2.1.3, } \\
\text { in order }\end{array}$} & 2.1.1. Get in the tractor \\
\hline & & 2.1.2. Activate the tractor \\
\hline & & 2.1.3. Check the presence of obstacles \\
\hline & & 2.1.4. Start the transit \\
\hline & \multirow{3}{*}{$\begin{array}{l}\text { 2.2. Road transit } \\
\text { Plan 2.2: do 2.2.1, 2.2.2, 2.2.3 }\end{array}$} & 2.2.1. Drive on the public road \\
\hline & & 2.2.2. Check the speed \\
\hline & & 2.2.3. Check the road traffic \\
\hline & \multirow{3}{*}{$\begin{array}{c}\text { 2.3. In-field transit } \\
\text { Plan 2.3: do } 2.3 .1,2.3 .2,2.3 .3\end{array}$} & 2.3.1. Drive in the field \\
\hline & & 2.3.2. Check the presence of obstacles \\
\hline & & 2.3.3. Check the speed \\
\hline & \multirow{5}{*}{$\begin{array}{c}\text { 2.4. Stop } \\
\text { Plan 2.4: do 2.4.1, 2.4.2, 2.4.3, } \\
\text { 2.4.4, } 2.4 .5\end{array}$} & 2.4.1. Check the presence of obstacles \\
\hline & & 2.4.2. Park the tractor \\
\hline & & 2.4.3. Switch off the tractor \\
\hline & & 2.4.4. Brake the tractor \\
\hline & & 2.4.4. Get out of the tractor \\
\hline
\end{tabular}


Table A1. Cont.

\begin{tabular}{|c|c|c|}
\hline Subtask & Elementary Task & Specific Activity \\
\hline \multirow{20}{*}{$\begin{array}{c}\text { 3. Application } \\
\text { Plan 3: do } 3.1 \text { then } 3.2 \text { or } 3.3 \\
\text { then } 3.2\end{array}$} & \multirow{3}{*}{$\begin{array}{c}\text { 3.1. Checking } \\
\text { Plan 3.1: do 3.1.1, 3.1.2, 3.1.3 } \\
\text { in order }\end{array}$} & 3.1.1. Check weather condition \\
\hline & & 3.1.2. Check the field condition \\
\hline & & 3.1.3. Check the PPE \\
\hline & \multirow{6}{*}{$\begin{array}{c}\text { 3.2. Product application } \\
\text { Plan 3.2: do 3.2.1, 3.2.2, 3.2.3 } \\
\text { and 3.2.4 then 3.2.5, 3.2.6 } \\
\text { then 3.2.1, 3.2.2, 3.2.3 and } \\
\text { 3.2.4 }\end{array}$} & 3.2.1. Reach the vineyard row \\
\hline & & 3.2.2. Activate the equipment \\
\hline & & 3.2.3. Apply the product \\
\hline & & 3.2.4. Check the speed of the tractor \\
\hline & & 3.2.5. Stop the equipment \\
\hline & & 3.2.6. Change the vineyard row \\
\hline & \multirow{11}{*}{$\begin{array}{c}\text { 3.3. In-field } \\
\text { setting/maintenance: } \\
\text { Plan 3.3: do 3.3.1, 3.3.2, 3.3.3, } \\
\text { 3.3.4, 3.3.5, 3.3.6, 3.3.7 and/or } \\
\text { 3.3.8, then 3.3.9, 3.3.10, 3.3.11 }\end{array}$} & 3.3.1. Reach a parking area \\
\hline & & 3.3.2. Park the tractor \\
\hline & & 3.3.3. Switch off the equipment \\
\hline & & 3.3.4. Switch off the tractor \\
\hline & & 3.3.5. Get out the tractor \\
\hline & & 3.3.6. Check the equipment \\
\hline & & 3.3.7. Regulate the sprayer \\
\hline & & 3.3.8. Regulate the pump \\
\hline & & 3.3.9. Get in the tractor \\
\hline & & 3.3.10. Activate the tractor \\
\hline & & 3.3.11. Reach the vineyard rows \\
\hline \multirow{13}{*}{$\begin{array}{l}\text { 4. Final operations } \\
\text { Plan 4: do } 4.1 \text { then } 4.2\end{array}$} & \multirow{8}{*}{$\begin{array}{c}\text { 4.1. External cleaning } \\
\text { Plan 4.1: do 4.1.1, 4.1.2, 4.1.3, } \\
\text { 4.1.4, 4.1.5, 4.1.6, 4.1.7, 4.1.8, } \\
\text { 4.1.9, } 4.1 .10,4.1 .11 \text { in order }\end{array}$} & 4.1.1. Reach the cleaning area \\
\hline & & 4.1.2. Park the tractor \\
\hline & & 4.1.3. Switch off the equipment \\
\hline & & 4.1.4. Switch off the tractor \\
\hline & & 4.1.5. Get out the tractor \\
\hline & & 4.1.6. Wash the equipment \\
\hline & & 4.1.9. Get in the tractor \\
\hline & & 4.1.10. Activate the tractor \\
\hline & \multirow{5}{*}{$\begin{array}{l}\text { 4.2. Disposal of residuals } \\
\text { Plan 4.2: do 4.2.1, 4.2.2, 4.2.3. }\end{array}$} & 4.2.1. Read instruction \\
\hline & & 4.2.2. Collect residuals \\
\hline & & 4.2.3. Dispose residuals \\
\hline & & 4.2.4. Dispose package \\
\hline & & 4.2.5. Update the register \\
\hline
\end{tabular}

\section{References}

1. Schreinemachers, P.; Tipraqsa, P. Agricultural pesticides and land use intensification in high, middle and low income countries. Food Policy 2012, 37, 616-626. [CrossRef]

2. Wesseler, J. Perspective: Regulation of pest and disease control strategies and why (many) economists are concerned. Pest Manag. Sci. 2019, 75, 578-582. [CrossRef] [PubMed]

3. Bondori, A.; Bagheri, A.; Allahyari, M.S.; Damalas, C.A. Pesticide waste disposal among farmers of Moghan region of Iran: Current trends and determinants of behavior. Environ. Monit. Assess. 2019, 191, 30. [CrossRef] [PubMed]

4. Wumbei, A.; Bawa, J.K.A.; Akudugu, M.A.; Spanoghe, P. Absence of Effects of Herbicides Use on Yam Rots: A Case Study in Wulensi, Ghana. Agriculture 2019, 9, 95. [CrossRef] 
5. Emery, S.B.; Hart, A.; Butler-Ellis, C.; Gerritsen-Ebben, M.G.; Machera, K.; Spanoghe, P.; Frewer, L.J. A review of the use of pictograms for communicating pesticide hazards and safety instructions: Implications for EU policy. Hum. Ecol. Risk Assess. Int. J. 2015, 21, 1062-1080. [CrossRef]

6. Jess, S.; Kildea, S.; Moody, A.; Rennick, G.; Murchie, A.K.; Cooke, L.R. European Union policy on pesticides: Implications for agriculture in Ireland. Pest Manag. Sci. 2014, 70, 1646-1654. [CrossRef]

7. Dugger-Webster, A.; LePrevost, C.E. Following pesticide labels: A continued journey toward user comprehension and safe use. Curr. Opin. Environ. Sci. Health 2018, 4, 19-26. [CrossRef]

8. Directive 2009/128/EC of the European Parliament and of the Council of 21 October 2009 Establishing a Framework for Community Action to Achieve the Sustainable Use of Pesticides. Available online: https://eur-lex.europa.eu/legal-content/EN/ALL/?uri=celex\%3A32009L0128 (accessed on 30 April 2019).

9. Jess, S.; Matthews, D.; Murchie, A.; Lavery, M. Pesticide Use in Northern Ireland's Arable Crops from 1992-2016 and Implications for Future Policy Development. Agriculture 2018, 8, 123. [CrossRef]

10. Biocca, M.; Gallo, P.; Imperi, G. Periodical Inspections and Controls of Agricultural Sprayers Already in Use in Italy Looking at the Directive CE 128/09. In Proceedings of the International Conference Work Safety and Risk Prevention in Agro-Food and Forest Systems, Ragusa SHWA 2010, Ragusa, Italy, 16-18 September 2010; pp. 517-520.

11. Zhang, X.; Guo, Q.; Shen, X.; Yiu, S.; Qiu, G. Water quality, agriculture and food safety in China: Current situation, trends, interdependencies, and management. J. Integr. Agric. 2015, 14, 2365-2379. [CrossRef]

12. McCauley, L.A.; Anger, W.K.; Keifer, M.; Langley, R.; Robson, M.G.; Rohlman, D. Studying health outcomes in farmworker populations exposed to pesticides. Environ. Health Perspect. 2006, 114, 953-960. [CrossRef]

13. Biocca, M.; Pochi, D.; Fanigliulo, R.; Gallo, P.; Pulcini, P.; Marcovecchio, F.; Perrino, C. Evaluating a filtering and recirculating system to reduce dust drift in simulated sowing of dressed seed and abraded dust particle characteristics. Pest Manag. Sci. 2017, 73, 1134-1142. [CrossRef]

14. Damalas, C.A.; Eleftherohorinos, I.G. Pesticide exposure, safety issues, and risk assessment indicators. Int. J. Environ. Res. Public Health 2011, 8, 1402-1419. [CrossRef]

15. Bagheri, A.; Emami, N.; Allahyari, M.S.; Damalas, C.A. Pesticide handling practices, health risks, and determinants of safety behavior among Iranian apple farmers. Hum. Ecol. Risk Assess. Int. J. 2018, 24, 2209-2223. [CrossRef]

16. Damalas, C.A.; Koutroubas, S.D. Farmers' exposure to pesticides: Toxicity types and ways of prevention. Toxics 2016, 4, 1. [CrossRef]

17. Khan, M.; Damalas, C.A. Factors preventing the adoption of alternatives to chemical pest control among Pakistani cotton farmers. Int. J. Pest Manag. 2015, 61, 9-16. [CrossRef]

18. Palis, F.G.; Flor, R.J.; Warburton, H.; Hossain, M. Our farmers at risk: Behaviour and belief system in pesticide safety. J. Public Health 2006, 28, 43-48. [CrossRef]

19. Yang, X.; Wang, F.; Meng, L.; Zhang, W.; Fan, L.; Geissen, V.; Ritsema, C.J. Farmer and retailer knowledge and awareness of the risks from pesticide use: A case study in the Wei River catchment, China. Sci. Total Environ. 2014, 497, 172-179. [CrossRef]

20. Mubushar, M.; Aldosari, F.O.; Baig, M.B.; Alhafi, B.M.; Kassem, H.S.; Khan, A.Q. Assessment of farmers on their knowledge regarding pesticide usage and biosafety. Saudi J. Biol. Sci. 2019. [CrossRef]

21. Sharifzadeh, M.S.; Abdollahzadeh, G.; Damalas, C.A.; Rezaei, R.; Ahmadyousefi, M. Determinants of pesticide safety behavior among Iranian rice farmers. Sci. Total Environ. 2019, 651, 2953-2960. [CrossRef]

22. Caffaro, F.; Micheletti Cremasco, M.; Roccato, M.; Cavallo, E. It does not occur by chance: A mediation model of the influence of workers' characteristics, work environment factors, and near misses on agricultural machinery-related accidents. Int. J. Occup. Environ. Health 2017, 23, 52-59. [CrossRef]

23. Moradhaseli, S.; Ataei, P.; Farhadian, H.; Ghofranipour, F. Farmers' Preventive Behavior Analysis Against Sunlight Using the Health Belief Model: A Study from Iran. J. Agromed. 2019, 24, 110-118. [CrossRef]

24. Fan, L.; Niu, H.; Yang, X.; Qin, W.; Bento, C.P.; Ritsema, C.J.; Geissen, V. Factors affecting farmers' behaviour in pesticide use: Insights from a field study in northern China. Sci. Total Environ. 2015, 537, 360-368. [CrossRef]

25. Yuantari, M.G.; Van Gestel, C.A.; Van Straalen, N.M.; Widianarko, B.; Sunoko, H.R.; Shobib, M.N. Knowledge, attitude, and practice of Indonesian farmers regarding the use of personal protective equipment against pesticide exposure. Environ. Monit. Assess. 2015, 187, 142. [CrossRef] 
26. Fargnoli, M.; Lombardi, M.; Haber, N.; Puri, D. The Impact of Human Error in the Use of Agricultural Tractors: A Case Study Research in Vineyard Cultivation in Italy. Agriculture 2018, 8, 82. [CrossRef]

27. Irwin, A.; Poots, J. Investigation of UK farmer go/no-go decisions in response to tractor-based risk scenarios. J. Agromed. 2018, 23, 154-165. [CrossRef]

28. Abadi, B. The determinants of cucumber farmers' pesticide use behavior in central Iran: Implications for the pesticide use management. J. Clean. Prod. 2018, 205, 1069-1081. [CrossRef]

29. Caffaro, F.; Schmidt, S.; Murphy, D.J.; Cavallo, E. Comprehension rates of safety pictorials affixed to agricultural machinery among Pennsylvania rural population. Saf. Sci. 2018, 103, 162-171. [CrossRef]

30. Irwin, A.; Caruso, L.; Tone, I. Thinking ahead of the tractor: Driver safety and situation awareness. J. Agromed. 2019, 1-10. [CrossRef]

31. Sharafi, K.; Pirsaheb, M.; Maleki, S.; Arfaeinia, H.; Karimyan, K.; Moradi, M.; Safari, Y. Knowledge, attitude and practices of farmers about pesticide use, risks, and wastes; a cross-sectional study (Kermanshah, Iran). Sci. Total Environ. 2018, 645, 509-517. [CrossRef]

32. Damalas, C.A.; Koutroubas, S.D. Farmers' behaviour in pesticide use: A key concept for improving environmental safety. Curr. Opin. Environ. Sci. Health 2018, 4, 27-30. [CrossRef]

33. Sadeghi, L.; Dantan, J.Y.; Siadat, A.; Marsot, J. Design for human safety in manufacturing systems: Applications of design theories, methodologies, tools and techniques. J. Eng. Des. 2016, 27, 844-877. [CrossRef]

34. Fargnoli, M.; Lombardi, M. Preliminary Human Safety Assessment (PHSA) for the Improvement of the Behavioral Aspects of Safety Climate in the Construction Industry. Buildings 2019, 9, 69. [CrossRef]

35. Lane, R.; Stanton, N.A.; Harrison, D. Applying hierarchical task analysis to medication administration errors. Appl. Ergon. 2006, 37, 669-679. [CrossRef]

36. Strand, G.O.; Haskins, C. On Linking of Task Analysis in the HRA Procedure: The Case of HRA in Offshore Drilling Activities. Safety 2018, 4, 39. [CrossRef]

37. Olivares, R.D.C.; Rivera, S.S.; Mc Leod, J.E.N. A novel qualitative prospective methodology to assess human error during accident sequences. Saf. Sci. 2018, 103, 137-152. [CrossRef]

38. Mitropoulos, P.; Cupido, G.; Namboodiri, M. Cognitive approach to construction safety: Task demand-capability model. J. Constr. Eng. Manag. 2009, 135, 881-889. [CrossRef]

39. Shepherd, A. HTA as a framework for task analysis. Ergonomics 1998, 41, 1537-1552. [CrossRef]

40. Mandal, S.; Singh, K.; Behera, R.K.; Sahu, S.K.; Raj, N.; Maiti, J. Human error identification and risk prioritization in overhead crane operations using HTA, SHERPA and fuzzy VIKOR method. Expert Syst. Appl. 2015, 42, 7195-7206. [CrossRef]

41. Embrey, D. Qualitative and quantitative evaluation of human error in risk assessment. In Human Factors for Engineers; Sandom, C., Harvey, R.S., Eds.; IET: London, UK, 2004; pp. 151-202, ISBN 0863413293.

42. Amato, V.; Valletta, M. Wine landscapes of Italy. In Landscapes and Landforms of Italy; Soldati, M., Marchetti, M., Eds.; Springer International Publishing: Cham, Switzerland, 2017; pp. 523-536. [CrossRef]

43. OIV (The International Organisation of Vine and Wine). State of the Vitiviniculture World Market Report-State of the Sector 2018. Available online: http://www.oiv.int/public/medias/6679/en-oiv-state-ofthe-vitiviniculture-world-market-2019.pdf (accessed on 20 May 2019).

44. Tegli, S.; Santilli, E.; Bertelli, E.; Surico, G. Genetic variation within Phaeoacremonium aleophilum and P. chlamydosporum in Italy. Phytopathol. Mediterr. 2000, 39, 125-133.

45. Pretorius, I.S.; Bauer, F.F. Meeting the consumer challenge through genetically customized wine-yeast strains. Trends Biotechnol. 2002, 20, 426-432. [CrossRef]

46. EUROSTAT. Agriculture, Forestry and Fishery Statistics, 2018th Edition ed. Available online: https://ec.europa.eu/eurostat/documents/3217494/9455154/KS-FK-18-001-EN-N.pdf (accessed on 30 April 2019).

47. Cividino, S.R.S.; Pergher, G.; Gubiani, R.; Moreschi, C.; Da Broi, U.; Vello, M.; Rinaldi, F. Definition of a Methodology for Gradual and Sustainable Safety Improvements on Farms and Its Preliminary Applications. Agriculture 2018, 8, 7. [CrossRef]

48. Vitali, M.; Protano, C.; Del Monte, A.; Ensabella, F.; Guidotti, M. Operative modalities and exposure to pesticides during open field treatments among a group of agricultural subcontractors. Arch. Environ. Contam. Toxic. 2009, 57, 193-202. [CrossRef] 
49. Cecchini, M.; Colantoni, A.; Monarca, D.; Cossio, F.; Riccioni, S. Survey on the status of enforcement of European directives on health and safety at work in some farms of central Italy. Chem. Eng. Trans. 2017, 58, 103-108. [CrossRef]

50. Lombardi, M.; Fargnoli, M. Prioritization of hazards by means of a QFD-based procedure. Int. J. Saf. Secur. Eng. 2018, 8, 342-353. [CrossRef]

51. Harris, D.; Stanton, N.A.; Marshall, A.; Young, M.S.; Demagalski, J.; Salmon, P. Using SHERPA to predict design-induced error on the flight deck. Aerosp. Sci. Technol. 2005, 9, 525-532. [CrossRef]

52. Ghasemi, M.; Khoshakhlagh, A.H.; Mahmudi, S.; Fesharaki, M.G. Identification and assessment of medical errors in the triage area of an educational hospital using the SHERPA technique in Iran. Int. J. Occup. Saf. Ergon. 2015, 21, 382-390. [CrossRef]

53. Di Pasquale, V.; Miranda, S.; Iannone, R.; Riemma, S. A simulator for human error probability analysis (SHERPA). Reliab. Eng. Syst. Saf. 2015, 139, 17-32. [CrossRef]

54. Salvendy, G. Handbook of Human Factors and Ergonomics, 4th ed.; John Wiley \& Sons, Inc.: Hoboken, NJ, USA, 2012; pp. 1-1732.

55. Ainsworth, L.K. Task analysis. In Human Factors for Engineers; Sandom, C., Harvey, R.S., Eds.; IET: London, UK, 2004; pp. 81-112, ISBN 0863413293.

56. Stanton, N.A. Hierarchical task analysis: Developments, applications, and extensions. Appl. Ergon. 2006, 37, 55-79. [CrossRef]

57. Salmon, P.; Jenkins, D.; Stanton, N.; Walker, G. Hierarchical task analysis vs. cognitive work analysis: Comparison of theory, methodology and contribution to system design. Theor. Issues Ergon. Sci. 2010, 11, 504-531. [CrossRef]

58. Baber, C.; Stanton, N.A. Human error identification techniques applied to public technology: Predictions compared with observed use. Appl. Ergon. 1996, 27, 119-131. [CrossRef]

59. Ghasemi, M.; Nasleseraji, J.; Hoseinabadi, S.; Zare, M. Application of SHERPA to identify and prevent human errors in control units of petrochemical industry. Int. J. Occup. Saf. Ergon. 2013, 19, 203-209. [CrossRef]

60. International Organization for Standardization (ISO). Safety of Machinery—Risk Assessment_Part 2: Practical Guidance and Examples of Methods; ISO/TR 14121-2:2012; International Organization for Standardization: Geneva, Switzerland, 2012.

61. PANE (Pesticide Action Network Europe). NAP Best Practice-Sustainable Use of Pesticides: Implementing a National Action Plan. 2010. Available online: https:/www.pan-europe.info/old/Resources/Reports/NAP_ best_practice.pdf (accessed on 30 April 2019).

62. Balsari, P.; Marucco, P. The new EU Directives requirements and the innovation in pesticide application techniques. J. ASTM Int. 2011, 8, 1-21. [CrossRef]

63. Cerruto, E.; Emma, G.; Failla, S.; Manetto, G. Survey on vineyards treatment and pesticide remnant management in Sicilian vine-growing farms. In Proceedings of the International Conference Work Safety and Risk Prevention in Agro-Food and Forest Systems, Ragusa SHWA 2010, Ragusa, Italy, 16-18 September 2010; pp. 389-395.

64. Pinto, A.; Nunes, I.L.; Ribeiro, R.A. Occupational risk assessment in construction industry-Overview and reflection. Saf. Sci. 2011, 49, 616-624. [CrossRef]

65. Hollnagel, E. Reliability analysis and operator modelling. Reliab. Eng. Syst. Saf. 1996, 52, 327-337. [CrossRef]

66. Elkind, P.D. Perceptions of Risk, Stressors, and Locus of Control Influence Intentions to Practice Safety Behaviors in Agriculture. J. Agromed. 2008, 12, 7-25. [CrossRef]

67. Caffaro, F.; Lundqvist, P.; Micheletti Cremasco, M.; Nilsson, K.; Pinzke, S.; Cavallo, E. Machinery-Related Perceived Risks and Safety Attitudes in Senior Swedish Farmers. J. Agromed. 2018, 23, 78-91. [CrossRef]

68. Allahyari, M.; Damalas, C.; Ebadattalab, M. Farmers' technical knowledge about integrated pest management (IPM) in olive production. Agriculture 2017, 7, 101. [CrossRef]

69. Bagagiolo, G.; Laurendi, V.; Cavallo, E. Safety Improvements on Wood Chippers Currently in Use: A Study on Feasibility in the Italian Context. Agriculture 2017, 7, 98. [CrossRef]

70. Damalas, C.A.; Koutroubas, S.D.; Abdollahzadeh, G. Drivers of Personal Safety in Agriculture: A Case Study with Pesticide Operators. Agriculture 2019, 9, 34. [CrossRef]

71. Rezaei, R.; Damalas, C.A.; Abdollahzadeh, G. Understanding farmers' safety behaviour towards pesticide exposure and other occupational risks: The case of Zanjan, Iran. Sci. Total Environ. 2018, 616, 1190-1198. [CrossRef] 
72. Caffaro, F.; Mirisola, A.; Cavallo, E. Safety signs on agricultural machinery: Pictorials do not always successfully convey their messages to target users. Appl. Ergon. 2017, 58, 156-166. [CrossRef]

73. Vigoroso, L.; Caffaro, F.; Cavallo, E. Warning against critical slopes in agriculture: Comprehension of targeted safety signs in a group of machinery operators in Italy. Int. J. Environ. Res. Public Health 2019, 16, 611. [CrossRef]

74. Kapeleka, J.; Mwaseba, D.L. Effectiveness of Pesticide Labels as A Communication Tool for Smallholder Farmers on Pesticides Handling. Int. J. Sci. Technol. Res. 2017, 6, 50-60.

75. Rother, H.A. Pesticide labels: Protecting liability or health?-Unpacking "misuse" of pesticides. Curr. Opin. Environ. Sci. Health 2018, 4, 10-15. [CrossRef]

76. Fargnoli, M.; Vita, L.; Gattamelata, D.; Laurendi, V.; Tronci, M. A reverse engineering approach to enhance machinery design for safety. In DS 70, Proceedings of the DESIGN 2012 12th International Design Conference, Dubrovnik, Croatia, 21-24 May 2012; Marjanovic, D., Storga, M., Pavkovic, N., Bojcetic, N., Eds.; The Design Society: Glasgow, UK, 2012; pp. 627-636, ISBN 978-953-7738-17-4.

77. Bhandari, G.; Atreya, K.; Yang, X.; Fan, L.; Geissen, V. Factors affecting pesticide safety behaviour: The perceptions of Nepalese farmers and retailers. Sci. Total Environ. 2018, 631, 1560-1571. [CrossRef]

78. Lyons, M. Towards a framework to select techniques for error prediction: Supporting novice users in the healthcare sector. Appl. Ergon. 2009, 40, 379-395. [CrossRef]

79. Damalas, C.A.; Khan, M. Farmers' attitudes towards pesticide labels: Implications for personal and environmental safety. Int. J. Pest. Manag. 2016, 62, 319-325. [CrossRef]

80. Fargnoli, M.; Lombardi, M.; Puri, D.; Casorri, L.; Masciarelli, E.; Mandić-Rajčević, S.; Colosio, C. The safe use of pesticides: A risk assessment procedure for the enhancement of occupational health and safety (OHS) management. Int. J. Environ. Res. Public Health 2019, 16, 310. [CrossRef]

81. Hughes, C.M.; Baber, C.; Bienkiewicz, M.; Worthington, A.; Hazell, A.; Hermsdörfer, J. The application of SHERPA (Systematic Human Error Reduction and Prediction Approach) in the development of compensatory cognitive rehabilitation strategies for stroke patients with left and right brain damage. Ergonomics 2015, 58, 75-95. [CrossRef]

82. Baxter, P.; Jack, S. Qualitative case study methodology: Study design and implementation for novice researchers. Qualit. Rep. 2008, 13, 544-559.

83. Cooper, R.J.; Fitt, P.; Hiscock, K.M.; Lovett, A.A.; Gumm, L.; Dugdale, S.J.; Rambohul, J.; Williamson, A.; Noble, L.; Beamish, J.; et al. Assessing the effectiveness of a three-stage on-farm biobed in treating pesticide contaminated wastewater. J. Eniron. Manag. 2016, 181, 874-882. [CrossRef]

84. Roettele, M.; Balsari, P.; Doruchowski, G.; Petersen, P.H. Sprayer development needs more focus on mitigation of environmental risks arising from point source water pollution (Results from the TOPPS project). Asp. Appl. Biol. 2010, 99, 123-132.

85. Thouvenin, I.; Bouneb, F.; Mercier, T. Operator dermal exposure and protection provided by personal protective equipment and working coveralls during mixing/loading, application and sprayer cleaning in vineyards. Int. J. Occup. Saf. Ergon. 2017, 23, 229-239. [CrossRef]

86. Suciu, N.A.; Ferrari, T.; Ferrari, F.; Trevisan, M.; Capri, E. Pesticide removal from waste spray-tank water by organoclay adsorption after field application to vineyards. Environ. Sci. Pollut. Res. 2011, 18, 1374-1383. [CrossRef]

87. Andersen, P.G.; Jørgensen, M.K.; Nilsson, E.; Wehmann, H.J. Towards efficient sprayer cleaning in the field and minimum point source pollution. Asp. Appl. Biol. 2010, 99, 49-53.

88. Doerpmund, M.; Cai, X.; Walgenbach, M.; Vondricka, J.; Lammers, P.S. Assessing the cleanability of a direct nozzle injection system. Biosyst. Eng. 2011, 110, 49-56. [CrossRef]

(C) 2019 by the authors. Licensee MDPI, Basel, Switzerland. This article is an open access article distributed under the terms and conditions of the Creative Commons Attribution (CC BY) license (http://creativecommons.org/licenses/by/4.0/). 